\title{
Macroeconomic and Public Health Policies amid COVID-19 Pandemic: Global Financial Sectors' Responses
}

\author{
Militcyano Samuel Sapulette ${ }^{\alpha^{*}}$, Teguh Santoso $^{\alpha}$
}

*Email: iansapulette@gmail.com

a Faculty of Economics and Business, Universitas Padjadjaran

Jl. Dipati Ukur No. 35, Bandung 40132

Riwayat artikel:

- Diterima 16 September 2020

- Direvisi 27 Desember 2020

- Disetujui 19 Januari 2021

- Tersedia online 12 Agustus 2021

\section{Abstract}

Given the unprecedentedness and scale of the COVID-19 pandemic, the impact and effectiveness of fiscal, monetary, and public health policies in response to the pandemic are largely unknown. This paper aims at presenting empirical evidence on the response of the financial sector to fiscal, monetary, and public health policies implemented during the pandemic. Using random effect estimation with data from 40 economies, we find that the financial sector does not respond significantly to fiscal stimulus, the monetary policy relaxation during the pandemic also has less magnitude of impact, stricter physical containment measures are also found to be positively and significantly affect financial sector performance.

Keywords: COVID-19; Monetary; Fiscal; Public Health; Financial

JEL Classification: E63; G1; I18 


\section{INTRODUCTION}

The COVID-19 pandemic has presented countries around the world with unprecedented challenges. The pandemic has caused a spike in uncertainty, including the uncertainty of near-term economic policy responses from the authorities. The level of uncertainty is unprecedented; the magnitude of uncertainty is even greater than one associated with the 2008 global financial crisis. These uncertainties have caused and will continue to cause large output contraction (Baker, Bloom, Davis, Kost, et al., 2020; Baker, Bloom, Davis, \& Terry, 2020; Goodell, 2020). Fernandes (2020) predicted that every additional month of the COVID-19 pandemic will cost 2.5-3\% of the global GDP. The economic impact of COVID-19 is felt in countries across the globe, both in emerging economies and in developed economies.

Both emerging and developed economies are severely impacted by the pandemic. Fernandes (2020) found that service-oriented economies, like in developed countries, will be more negatively affected; people in service-oriented economies will have more jobs that are at risk because of the COVID-19 pandemic. On the other hand, developing countries are also at risk of a large negative impact because of "lower health care capacity, larger informal sectors, shallower financial markets, less fiscal space, and poorer governance" (Loayza \& Pennings, 2020). The impact of the pandemic extends to various sectors of the economy in emerging and developed economies, including the financial sector.

The financial sector has been hit hard by the COVID-19 pandemic. The pandemic has brought exceptional shocks in this sector (Baker, Bloom, Davis, Kost, et al., 2020). There is a clear pattern in the financial market before and after the pandemic: there is a substantial increase in volatility globally (Zhang, Hu, \& Ji, 2020). Moreover, the COVID-19 pandemic has seen a spike in local currency bond spreads, sharp depreciation of currencies, and capital outflow from developing countries (Hofmann, Shim, \& Shin, 2020). Banks and non-bank financial institutions have also been affected. The pandemic has caused an economic downturn which led to increased vulnerability of these financial institutions. These financial institutions face a higher likelihood of an increase in nonperforming loans, and the possibility of, in extreme cases for banks, bank runs (Goodell, 2020). Furthermore, during the pandemic, there have been declines in card payments and ATM use which negatively impacted banks' profits. Nonbank financial institutions like fintech companies also faced a decrease in the patronage of consumer lending which has led to a decrease in their profitability and investment from venture capitalists (Ozili $\&$ Arun, 2020). These impacts of the COVID-19 pandemic have triggered authorities around the world to respond with an array of policies.

To counter the negative impact of the COVID-19 pandemic, authorities around the globe have issued policies ranging from the conventional macroeconomic fiscal and monetary policies to novel public health policies. Almost all countries have typically responded with immediate fiscal and monetary policies. These policies are, however, predicted to be less effective in developing countries because of weak monetary policy transmission, weak fiscal space, and small fiscal multipliers (Loayza $\&$ Pennings, 2020). Public health policies like social distancing and lockdown have also been implemented, but with various degrees of public compliance in countries around the world (Ozili \& Arun, 2020). Aside from the aimed positive impact on the economy, these policies have, nonetheless, caused a spillover effect of increased uncertainty especially in the financial market (Baker, Bloom, Davis, $\&$ Terry, 2020; Zhang et al., 2020).

The COVID-19 pandemic has caused unprecedented shocks to the financial sector in economies around the world. The negative impact on the economy has been responded to by immediate monetary, fiscal, and public health measures. Considering the unprecedentedness of an event like the COVID-19 pandemic, the effect of monetary, fiscal, and public health policy responses, especially on the financial sector, during such events is also unknown. This paper aims at providing early empirical evidence on the responses of financial sectors to monetary, fiscal, and public health policies during the COVID-19 pandemic. To reach this objective, the random effect estimation is employed using data from 20 developed and 20 emerging economies. Financial sectors are proxied by financial sector stock market returns from the 40 economies sampled in this research. The findings of this study provide insights and empirical underpinning for policymakers around the world in mitigating the negative impacts of the COVID-19 pandemic on the financial sectors. 
This paper is divided into five sections. The next section provides a review of related literature. Section three presents the data and method of this research. The fourth section contains the result of the random effect estimation and discussions of the findings. Conclusions and recommendations are presented in the last chapter.

\section{LITERATURE REVIEW}

COVID-19 pandemic has negatively impacted the financial sector. Ozili and Arun (2020) argued that the pandemic has caused a decline in financial companies' performances. The reason for this is that during the COVID-19 pandemic, there has been a decline in financial transactions which then led to lower profitability of financial firms. In line with Ozili and Arun (2020), Goodell (2020) also cites the increase in vulnerability of the financial sector during an economic downturn caused by the COVID-19 pandemic as the reason. These arguments are evident in the stock market across the globe. In the early months of the COVID-19 pandemic, stock markets around the world experienced significant plunges but then recovered in the following months (Baker, Bloom, Davis, Kost, et al., 2020).

Mckibbin and Fernando (2020) studied the impact of the COVID-19 pandemic on macroeconomic outcomes and financial market in a global hybrid DSGE/CGE general equilibrium model. Their study suggests that a combination of macroeconomic (fiscal and monetary) and public health policies must be done to mitigate the negative impact of the COVID-19 pandemic.

Regarding the effectiveness of fiscal policy responses to the COVID-19 pandemic, the consensus tends to be that fiscal policies during the COVID-19 pandemic may be inefficient. Loayza and Pennings (2020) studied macroeconomic policy responses in developing countries. Their findings suggest that the short-term goals of policies designed to counter the COVID-19 economic impact must not be focused on stimulating the economy but rather to "avoid mass layoffs and bankruptcies". Having economic stimulation as a short-run goal of COVID-19 policy response is futile since there are supplyrestricting containment measures. They also state fiscal stimulus may be ineffective in developing countries given weak fiscal space and small fiscal multipliers. Agreeing with this argument, Guerrieri et al. (2020) argued that, both in developed and emerging economies, fiscal stimulus may not be as effective as usual since some economic sectors are shut down, which mutes the Keynesian multiplier feedback.

Chatziantoniou, Duffy, and Filis (2013) studied the impact of fiscal policy on the stock market. It states that, from a theoretical point of view, the effectiveness of conventional fiscal stimulus on the economy depends on whether one takes the Keynesian, Classical, or Ricardian view. The actual impact of fiscal policy such as fiscal stimulus on the stock market is still debatable. Their empirical findings suggest that there is no evidence of the direct impact of fiscal policy on the stock market return.

There is a clear consensus regarding the impact of monetary policy on the stock market. The impact of expansionary monetary policy tends to be positive and significant, while contractionary monetary policy tends to negatively impact the stock market (Conover, Jensen, \& Johnson, 1999; Ehrmann \& Worms, 2004; English, Nelson, \& Sack, 2003; Thorbecke \& Coppock, 1997). Regarding the magnitude of market reaction to monetary policy response to events that resemble (although not closely given the unprecedentedness of such pandemic) the COVID-19, the consensus drawn from relevant literature suggests that it depends on whether the monetary policy is expected or unexpected. Basistha and Kurov (2008) examined cyclical variation in the effect of Fed policy on the stock market. They found that a surprise (unexpected) monetary easing "reduces the quantity restrictions on the availability of credit, resulting in a larger effect on the level of economic activity" compared to an expected one.

Zhang, Hu, and Ji (2020) examined country-specific risk and systemic risk in the global financial markets during the COVID-19 pandemic. They found that the expansionary monetary policies adopted by various countries can save the financial sector as shown in the financial market, at least in the short run. They argue that expansionary monetary policies have helped stopped the panic investors. Agreeing with this finding, Ozili and Arun (2020), which studied the impact of fiscal, monetary, and public health policies during COVID-19 on stock return and economic activity, found that the increase in central bank policy rate negatively affects economic activity and stock price.

Besides the fiscal and monetary policy responses in mitigating the COVID-19 pandemic impact on the economy, public health measures have been executed to mitigate the impact. Public health measure 
precedes fiscal and monetary responses given the COVID-19 pandemic is foremost a public health issue. Mckibbin and Fernando (2020) found that public health measures such as quarantining infected people and the restriction of large-scale social interactions are an effective response. The public health measures will reduce the social and economic cost of the COVID-19 pandemic in the long-run. Agreeing with this finding, Ozili and Arun (2020) also found that imposed restrictions on movements within a country positively impact the stock prices of that country.

\section{RESEARCH METHOD}

\section{A. Data}

The data used in this research span from January 2019 to May 2020. The data include 20 developed economies and 20 emerging economies. The 40 economies sampled are countries that have financial sector index in their stock markets and are also included in the Fama and French developed and emerging economies Five-Factor portfolio (accessible at http://mba.tuck.dartmouth.edu). The inclusion of data from the pre-COVID-19 pandemic period is meant to show the performance of financial sector stock before and during the pandemic (aided by dummy variables). Moreover, with this period span, we are also able to show the magnitude of monetary policy effect in the two periods.

We use Fama and French Five-Factor Model (FF5 model) (Fama \& French, 2015, 2017) to sufficiently model the financial sector stock return (Elyasiani, Mansur, \& Odusami, 2011; Li, Spigt, \& Swinkels, 2017). The variables of interest are added to this FF5 model. The variables of interest in this research are central bank policy rate, fiscal stimulus for COVID-19 mitigation, and social distancing compliance.

Figure 1 Average Financial Sector Stock Index

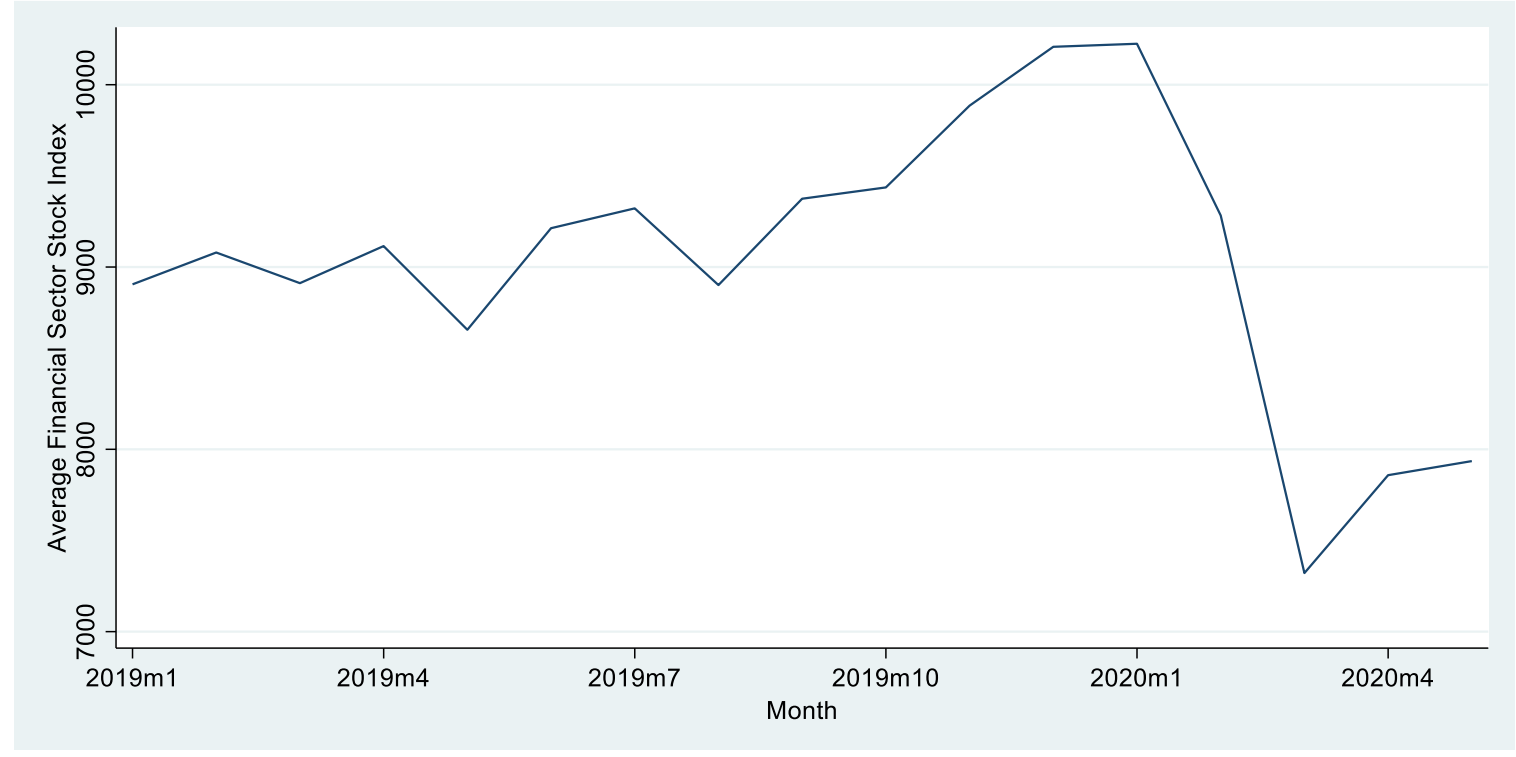

Figure 1 above shows the average financial sector stock index in 40 economies sampled in this research. There is a clear pattern in all the sampled economies: they all experienced downturn in stock return in the months close to the first case COVID-19 in the respected economies. From that downturn, the stock price then rebounded until the end of the sample period. The financial sector stock index is the monthly return of the leading financial sector stock index in each economy. The leading financial sector stock index is shown in Table 1 below. 
Table 1 Financial Sector Stock Index

\begin{tabular}{|c|c|c|c|}
\hline $\begin{array}{l}\text { Economy } \\
\text { (Developed) }\end{array}$ & Index & $\begin{array}{l}\text { Economy } \\
\text { (Emerging) }\end{array}$ & Index \\
\hline Australia & S\&P/ASX 200 Financials & Brazil & Financials \\
\hline Austria & ATX Financials & China & FTSE China Financials \\
\hline Belgium & BEL Financials Net Return & Egypt & EFG-Hermes Financials \\
\hline Canada & S\&P/TSX Canadian Financials & Greece & FTSE Financial Services \\
\hline Germany & DAX Financial Services & India & Nifty Financial Services \\
\hline Denmark & Copenhagen Financials & Indonesia & IDX Finance \\
\hline Spain & Madrid Financial Services & Malaysia & KL Finance \\
\hline Finland & Helsinki Financials & Mexico & S\&P/BMV-FINAN RT \\
\hline France & CAC Financials & Peru & S\&P Lima Banks \\
\hline Great Britain & FTSE All Share Financials & Philippines & PHS Banks And Financial \\
\hline Hong Kong & HSI-Finance & Poland & WIG Banks \\
\hline Ireland & ISEQ Financial & Qatar & Banking \\
\hline Italy & $\begin{array}{l}\text { FTSE Italia All Share Financial } \\
\text { Services }\end{array}$ & Russia & MOEX Financials \\
\hline Japan & Tokyo SE TOPIX17 Financials & Saudi Arabia & Diversified Financials \\
\hline Netherlands & AEX Financials & South Africa & FTSE/JSE Financial 15 \\
\hline Norway & Oslo GICS 40 Financial & South Korea & KOSDAQ Financials \\
\hline New Zealand & S\&P/NZX Financials Capital & Taiwan & Taiwan Finance \\
\hline Portugal & PSI Financials Gross Return & Thailand & SET Financials \\
\hline Sweden & Stockholm Financials & Turkey & Financials \\
\hline United States & Dow Jones Financials & $\begin{array}{l}\text { United Arab } \\
\text { Emirates }\end{array}$ & $\begin{array}{l}\text { Dubai Finance and } \\
\text { Investment }\end{array}$ \\
\hline
\end{tabular}

Figure 2 Average Central Bank Policy Rate

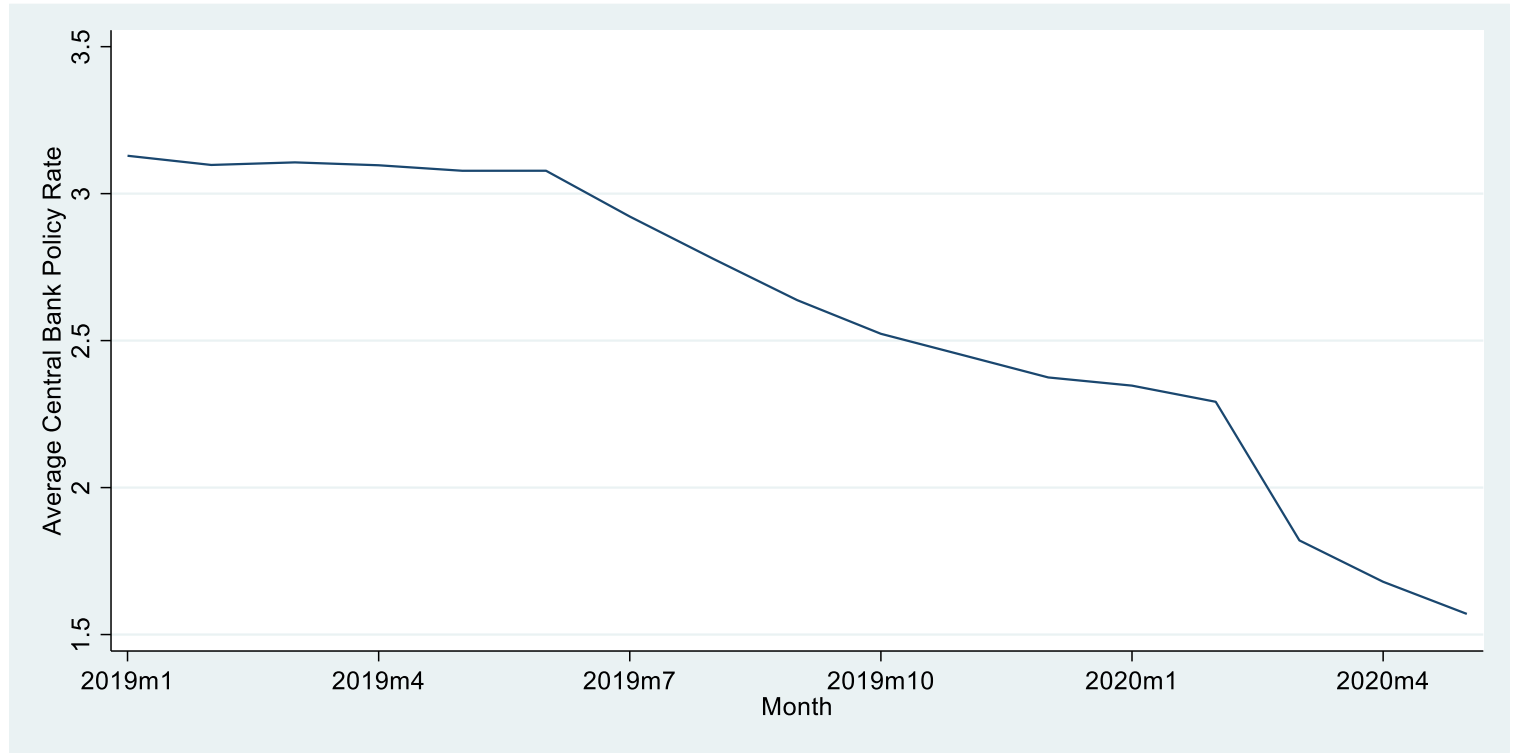

Figure 2 shows the development of the central bank policy rate. Before the COVID-19 pandemic, the trend varies; since the start, many central banks decided to immediately lower their policy rate. Some notable exceptions include the European Central Bank that kept its policy rate constant at 0\% even during the pandemic. The date was obtained from the Bank for International Settlements statistical database (accessible at https://www.bis.org/statistics).

Since the start of the Pandemic, almost all economies have responded with some kind of fiscal stimulus program. The amount of pledged fiscal stimulus varies from country to country. IMF provides the data of the amount of fiscal stimulus in response to the COVID-19 pandemic for almost all economies. The date is accessible at https://www.imf.org/en/Topics/imf-and-covid19/Policy- 
Responses-to-COVID-19. Table 2 below presents the summary of the total fiscal stimulus of each country as a percentage of that country's 2019 nominal GDP (as of May 2020).

Table 2 Fiscal Stimulus (\% of 2019 Nominal GDP)

\begin{tabular}{|c|c|c|c|}
\hline Economy (Developed) & Fiscal Stimulus & Economy (Emerging) & Fiscal Stimulus \\
\hline Australia & 9 & Brazil & 11.8 \\
\hline Austria & 13 & China & 4.1 \\
\hline Belgium & 14.1 & Egypt & 1.8 \\
\hline Canada & 12.4 & Greece & 14 \\
\hline Germany & 33 & India & 11.8 \\
\hline Denmark & 5.7 & Indonesia & 4.4 \\
\hline Spain & 10.8 & Malaysia & 18.96 \\
\hline Finland & 3 & Mexico & 2 \\
\hline France & 14 & Peru & 2.2 \\
\hline Great Britain & 14.5 & Philippines & 3.1 \\
\hline Hong Kong & 15 & Poland & 12.4 \\
\hline Ireland & 4 & Qatar & 13 \\
\hline Italy & 29.6 & Russia & 4.45 \\
\hline Japan & 21.1 & Saudi Arabia & 10.48 \\
\hline Netherlands & 9.3 & South Africa & 8.6 \\
\hline Norway & 5.5 & South Korea & 13.68 \\
\hline New Zealand & 6 & Taiwan & 5.4 \\
\hline Portugal & 11.15 & Thailand & 14.9 \\
\hline Sweden & 16.6 & Turkey & 10.8 \\
\hline United States & 12.1 & United Arab Emirates & 2 \\
\hline
\end{tabular}

Figure 3 below presents the data for the proxy of social distance compliance in the 40 economies. Google Mobility Index (accessible at https://www.google.com/covid19/mobility/) is used as the proxy for social distancing compliance following Mohler et al. (2020). The data index shows a decrease in total mobility relative to the baseline level (before February 2020). Before February the mobility level is assumed to be at the baseline level. Besides the above-mention variables, several dummy variables and interaction dummy variables are also included in the model. The variables are further detailed in the next subsection.

Figure 3 Average Google Mobility Index

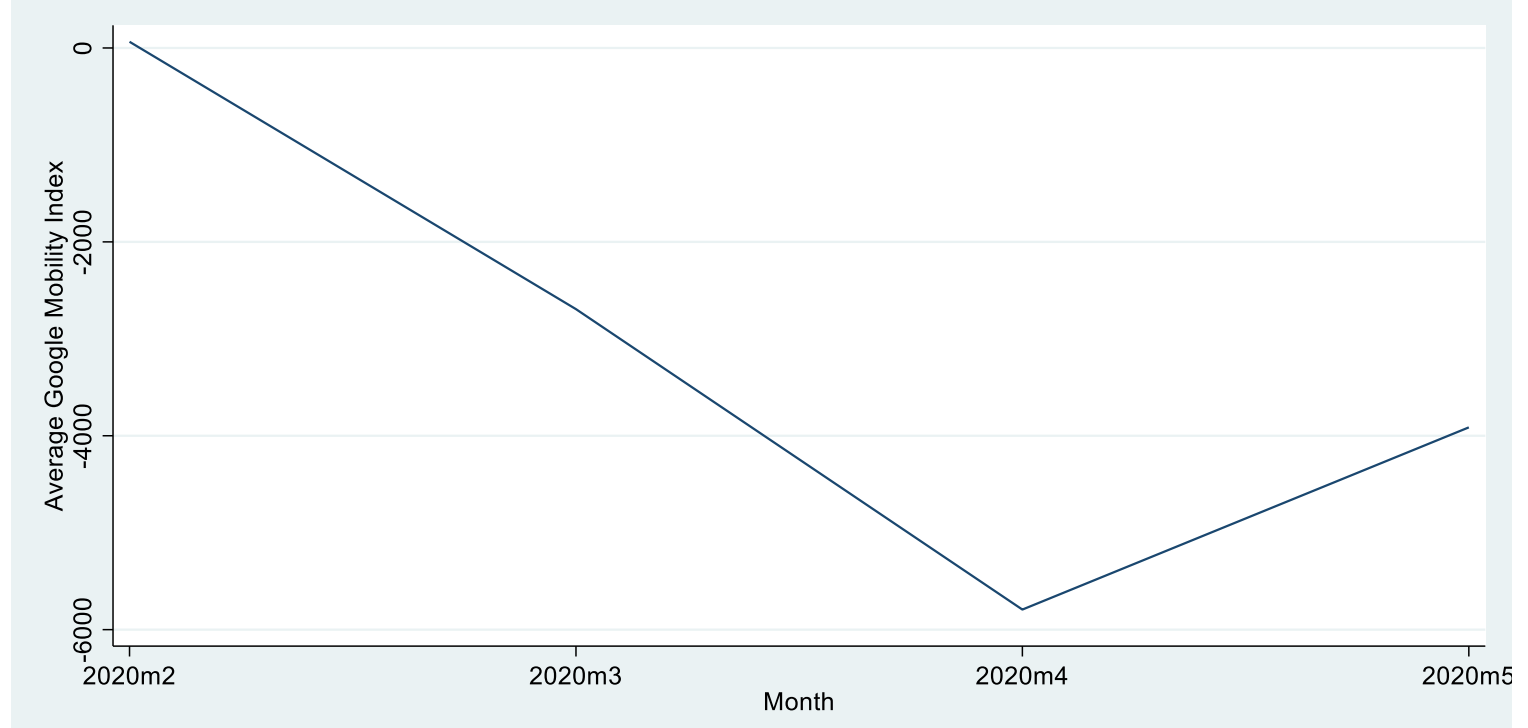




\section{B. Method}

To see the impact of fiscal, monetary, and public health policy responses on the financial sector, this research utilizes Fama and French Five-Factor Model (Fama \& French, 2015, 2017) with additional variables representing fiscal, monetary, and public health policy responses. Dummy variables representing the COVID-19 pandemic period, emerging/developed country; and interaction dummy variables between pandemic period and central bank policy rate, emerging/developed dummy and pandemic period are also included in the model. The model used in this research is shown in the equation.

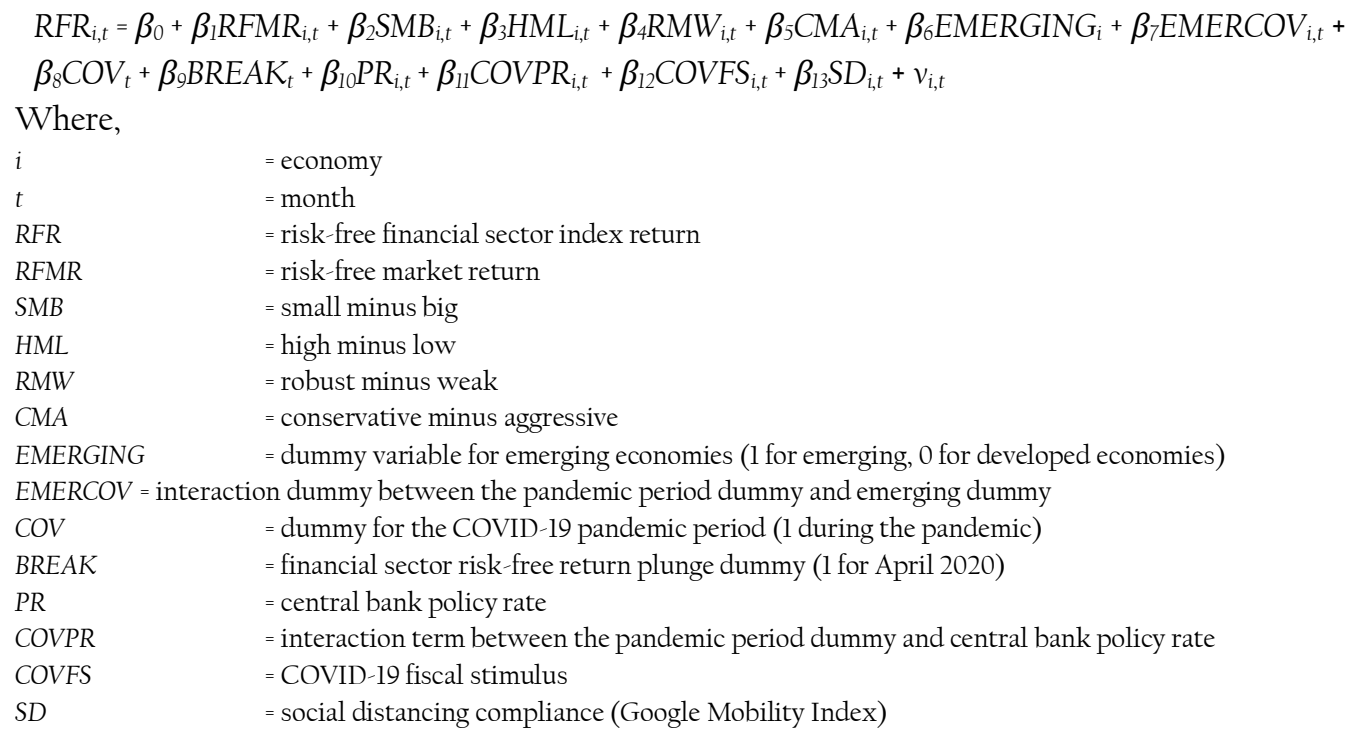

Considering the panel data structure with time-invariant dummy variables, this research employs a random effect estimation method to estimate the model. The random effect model (REM) or error components model (ECM) assumes the bank-specific intercepts to be distributed independently of the regressors and are included in the error term. Each bank has the same coefficients/slope parameters for every regressor and a composite error term $\left(v_{i, t}=a_{i}+u_{i, t}\right)$. The estimation result is checked for heteroscedasticity, multicollinearity, and autocorrelation assumptions. To check for the robustness of the estimation result, we modify the model by removing $R M W$ and CMA variables (thus making it Fama and French Three-Factor Model) (estimation result for this model is presented in the appendix) (Li et al., 2017; Wooldridge, 2010).

\section{RESULT ANALYSIS AND DISCUSSION}

Table 3 below presents the result of the random effect estimation with White robust standard error. The White robust standard error is used to correct for heteroscedasticity at a 5\% significance level found in the initial estimation. The estimation result of the Three-Factor Model (appendix) has almost identical estimation results for the variables of interest, thus implying the robustness of this estimation result.

As seen in Table 3, the majority of variables are significant at a $1 \%$ significance level. The only variables that are not significant even at a $10 \%$ significance level are EMERCOV and COVFS. Furthermore, all Fama and French Five-Factor variables are significant at a 5\% significance level, confirming the sufficiency of this Five-Factor Model in modeling financial sector stock return. The overall $\mathrm{R}^{2}$ is at $42.3 \%$ meaning $42.3 \%$ of variations in financial sector stock market return is explained by variables in the model, the reset is explained by other variables outside the model.

The emerging economy dummy variable (EMERGING) is negative and significant while the emerging country during pandemic interaction term (EMERCOV) is insignificant. This finding 
supports the arguments of Fernandes (2020). Before the COVID-19 pandemic, emerging economies had significantly lower monthly financial sector risk-free returns than the developed economies as seen from the coefficient of the EMERGING variable, but as shown by the insignificance of the EMERCOV variable, the difference became highly insignificant during the pandemic. This result proves that the financial sector in economies that are more service-oriented (developed economies) are more negatively impacted by the COVID-19 pandemic than financial sectors in relatively less service-oriented economies.

The pandemic period dummy (COV) has a positive and significant impact on financial sector stock return, while the BREAK dummy which represents a plunge in stock market risk-free return price because of the COVID-19 pandemic is negative and significant. This finding corresponds to the stock market trend in early 2020. The stock market across the globe plunged to an extreme low in the early months of the COVID-19 pandemic but then rebounded in the following months (Baker, Bloom, Davis, Kost, et al., 2020).

The dummy variables representing the central bank policy rate (PR and COVPR) are both negative and significant. The difference lies in the magnitude of the variables' coefficients. The before-pandemic central bank policy rate (PR) is larger than the during-pandemic one. There are two possible explanations for this finding. The first argument is that the decrease in policy rate had been largely expected by the financial sector, thus there was no surprise when the central banks implemented this policy. The absence of surprise contributed to the lower magnitude of the monetary policy effect because the market had expected the policy and anticipated its impact accordingly (Basistha \& Kurov, 2008). This argument, however, is against the findings of Baker, Bloom, Davis, and Terry (2020) and Zhang, Hu, and Ji (2020) which argued that the uncertainty in the financial sector because of the COVID-19 pandemic, including policy uncertainty, is on an unprecedented level. This left us with the second argument. The second supporting argument for this finding is that the monetary relaxation during the COVID-19 pandemic is less effective because the pandemic is largely a supply shock, supporting the arguments of Cochrane (2020), Mckibbin and Fernando (2020). They argue for a combination of fiscal, monetary, and public health policies to be executed in a coordinated manner since the impact of monetary policy itself is less significant during the COVID-19 pandemic than in normal times. 
Table 3 Estimation Result

\begin{tabular}{|c|c|}
\hline Variables & $b / s e$ \\
\hline \multirow[t]{2}{*}{ RFMR } & $0.0173 * * *$ \\
\hline & 0.00183 \\
\hline \multirow[t]{2}{*}{$S M B$} & $0.0318^{* *}$ \\
\hline & 0.015 \\
\hline \multirow[t]{2}{*}{$H M L$} & $0.0332 * * *$ \\
\hline & 0.00682 \\
\hline \multirow[t]{2}{*}{$R M W$} & $0.0706 * * *$ \\
\hline & 0.0145 \\
\hline \multirow[t]{2}{*}{ CMA } & $0.0684 * * *$ \\
\hline & 0.0147 \\
\hline \multirow[t]{2}{*}{ EMERGING } & $-1.848 * * *$ \\
\hline & 0.67 \\
\hline \multirow[t]{2}{*}{ EMERCOV } & 0.0278 \\
\hline & 0.0732 \\
\hline \multirow[t]{2}{*}{ COV } & $1.061 * * *$ \\
\hline & 0.0802 \\
\hline \multirow[t]{2}{*}{ BREAK } & $-0.145^{* *}$ \\
\hline & 0.0638 \\
\hline \multirow[t]{2}{*}{$P R$} & $-0.131 * * *$ \\
\hline & 0.0431 \\
\hline \multirow[t]{2}{*}{ COVPR } & $-0.0927 * * *$ \\
\hline & 0.0164 \\
\hline \multirow[t]{2}{*}{ COVFS } & -0.00268 \\
\hline & 0.00504 \\
\hline \multirow[t]{2}{*}{$S D$} & $-0.0000869 * * *$ \\
\hline & 0.0000139 \\
\hline \multirow[t]{2}{*}{ CONS } & $-3.041 * * *$ \\
\hline & 0.296 \\
\hline R-Sqr Within & 0.653 \\
\hline R-Sqr_Between & 0.405 \\
\hline R-Sqr Overall & 0.423 \\
\hline
\end{tabular}

According to our estimation, the impact of fiscal stimulus on the financial sector is insignificant. The COVFS variable which represents fiscal stimulus because of the COVID-19 pandemic has a $p$-value of .595 which means that the variable is highly insignificant. This finding is in line with the findings of Chatziantoniou, Duffy, and Filis (2013); Guerrieri et al. (2020); and Loayza and Pennings (2020). As stated in their papers, the fiscal stimulus may be inefficient because of (1) the existence of supplyrestricting containment measures, (2) weak fiscal space in developing countries, and (3) small fiscal multiplier in developing countries.

Contras to the effect of fiscal stimulus, social distancing compliance shows a significant effect on the financial sector stock return. The social distancing compliance (SD) has a negative effect on the financial sector stock market return, meaning a decrease of human mobility (i.e. stricter social distancing policy) is responded positively by the financial sector. These findings support the finding of Ozili and Arun (2020). Their empirical estimation also shows a positive stock market response to an increase in social distancing within a country. This finding can also be linked with the arguments put forward by Guerrieri et al. 2020, Mckibbin and Fernando (2020). They argued that although physical containment measures like social distancing or even lockdown are relatively costly in the short run these kinds of policies are the optimal ones since they can help the economy recover faster and preventing further unnecessary possible output loss because of the pandemic. The financial sector also seems to think this way. 


\section{CONCLUSION AND RECOMMENDATION}

This paper aims at providing early empirical evidence on the responses of financial sectors to macroeconomic and public health policies during the COVID-19 pandemic. Random effect estimation with White robust standard error using data from 40 economies is employed to reach this objective. The estimation result shows that the financial sector does not respond significantly to fiscal stimulus during the COVID-19 pandemic. On the other hand, the monetary policy relaxation during the pandemic significantly contributes to the increase in financial sector performance. However, it is found that the magnitude of the effect of monetary relaxation is smaller during the COVID-19 pandemic than in normal times. Regarding the impact of public health policy, this study finds that stricter physical containment measures are found to be positively and significantly related to financial sector performance. Furthermore, this study also finds that the financial sectors in developed economies are more negatively affected by the COVID-19 pandemic than the financial sectors in emerging economies.

Based on the existing literature and the findings of this research, we recommend policy makers to focus on a policy mix that combines fiscal, monetary, and public health measures with their effectiveness in mind. Unconventional fiscal, monetary, and macro-prudential policies should also be explored and added to financial authorities' arsenal to assist the conventional macroeconomic policies that have been implemented. The policy makers should also focus on finding the optimal physical containment measures so that the economy can soon get back to normal without further costly loss in lives and economic output.

\section{REFERENCE}

Baker, S., Bloom, N., Davis, S., Kost, K., Sammon, M., \& Viratyosin, T. (2020). The Unprecedented Stock Market Impact of COVID-19. National Bureau of Economic Research. https://doi.org/10.3386/w26945

Baker, S., Bloom, N., Davis, S., \& Terry, S. (2020). COVID-Induced Economic Uncertainty. National Bureau of Economic Research. https://doi.org/10.3386/w26983

Basistha, A., \& Kurov, A. (2008). Macroeconomic Cycles and the Stock Market's Reaction to Monetary policy. Journal of Banking and Finance, 32(12), 2606-2616. https://doi.org/10.1016/j.jbankfin.2008.05.012

Chatziantoniou, I., Duffy, D., \& Filis, G. (2013). Stock Market Response to Monetary and Fiscal Policy Shocks: Multi-Country Evidence. Economic Modelling, 30(1), 754-769. https://doi.org/10.1016/j.econmod.2012.10.005

Cochrane, J. (2020). Coronavirus Monetary Policy. In Economics in the Time of Covid-19 (pp. 105-108).

Conover, C. M., Jensen, G. R., \& Johnson, R. R. (1999). Monetary environments and international stock returns. Journal of Banking and Finance. https://doi.org/10.1016/S0378-4266(99)00007-2

Ehrmann, M., \& Worms, A. (2004). Bank networks and monetary policy transmission. Journal of the European Economic Association. https://doi.org/10.1162/1542476042813904

Elyasiani, E., Mansur, I., \& Odusami, B. (2011). Oil Price Shocks and Industry Stock Returns. Energy Economics, 33(5), 966-974. https://doi.org/10.1016/j.eneco.2011.03.013

English, W. B., Nelson, W. R., \& Sack, B. P. (2003). Interpreting the significance of the lagged interest rate in estimated monetary policy rules. Contributions to Macroeconomics. https://doi.org/10.2202/1534-6005.1073

Fama, E. F., \& French, K. R. (2015). A five-factor asset pricing model. Journal of Financial Economics. https://doi.org/10.1016/j.jfineco.2014.10.010

Fama, E. F., \& French, K. R. (2017). International Tests of a Five-Factor Asset Pricing Model. Journal of Financial Economics, 123(3), 441-463. https://doi.org/10.1016/j.jineco.2016.11.004

Fernandes, N. (2020). Economic Effects of Coronavirus Outbreak (COVID-19) on the World Economy. SSRN Electronic Journal, ISSN 1556-5068, Elsevier BV, 0-29.

Goodell, J. W. (2020). COVID-19 and Finance: Agendas for Future Research. Finance Research Letters, 35(March). https://doi.org/10.1016/j.frl.2020.101512 
Guerrieri, V., Lorenzoni, G., Straub, L., \& Werning, I. (2020). Macroeconomic Implications of Covid19: Can Negative Supply Shocks Cause Demand Shortages? In NBER WORKING PAPER SERIES. https://doi.org/10.1017/CBO9781107415324.004

Hofmann, B., Shim, I., \& Shin, H. S. (2020). Emerging Market Economy Exchange Rates and Local Currency Bond Markets amid the Covid-19 Pandemic. BIS Bulletin, (5).

Li, Y., Spigt, R., \& Swinkels, L. (2017). The impact of FinTech start-ups on incumbent retail banks' share prices. Financial Innovation, 3(1). https://doi.org/10.1186/s40854-017-0076-7

Loayza, N. V., \& Pennings, S. (2020). Macroeconomic Policy in the Time of COVID-19. Macroeconomic Policy in the Time of COVID-19. https://doi.org/10.1596/33540

Mckibbin, W., \& Fernando, R. (2020). The Global Macroeconomic Impacts of COVID-19: Seven Scenarios. SSRN Electronic Journal, 2(4), 12-22. Retrieved from https://ssrn.com/abstract=3547729

Mohler, G., Bertozzi, A. L., Carter, J., Short, M. B., Sledge, D., Tita, G. E., ... Brantingham, P. J. (2020). Impact of Social Distancing During COVID-19 Pandemic on Crime in Los Angeles and Indianapolis. Journal of Criminal Justice, 68(March), 101692. https://doi.org/10.1016/j.jcrimjus.2020.101692

Ozili, P. K., \& Arun, T. (2020). Spillover of COVID-19: Impact on the Global Economy. SSRN Electronic Journal. https://doi.org/10.2139/ssrn.3562570

Thorbecke, W., \& Coppock, L. (1997). Why good economic news depressed stock and bond prices in 1996. Economics Letters. https://doi.org/10.1016/s0165-1765(97)00038-4

Wooldridge, J. M. (2010). Econometric Analysis of Cross Section and Panel Data. In MIT Press (2nd ed.). https://doi.org/10.2307/j.ctv5rdzwc.l

Zhang, D., Hu, M., \& Ji, Q. (2020). Financial Markets Under the Global Pandemic of COVID-19. Finance Research Letters, (March), 101528. https://doi.org/10.1016/j.frl.2020.101528 
7. APPENDIX: ESTIMATION RESULT WITH FAMA AND FRENCH THREE-FACTOR MODEL

\begin{tabular}{|c|c|}
\hline Variables & $b / s e$ \\
\hline \multirow[t]{2}{*}{ RFMR } & $0.0121 * * *$ \\
\hline & 0.00341 \\
\hline \multirow[t]{2}{*}{$S M B$} & $0.0230 * *$ \\
\hline & 0.0115 \\
\hline \multirow[t]{2}{*}{$H M L$} & $0.0375^{* * *}$ \\
\hline & 0.00884 \\
\hline \multirow[t]{2}{*}{ EMERGING } & $-1.880^{* * *}$ \\
\hline & 0.568 \\
\hline \multirow[t]{2}{*}{ EMERPAN } & 0.012 \\
\hline & 0.088 \\
\hline \multirow[t]{2}{*}{ PAN } & $0.936 * * *$ \\
\hline & 0.0916 \\
\hline \multirow[t]{2}{*}{ BREAK } & 0.00466 \\
\hline & 0.0983 \\
\hline \multirow[t]{2}{*}{$P R$} & $-0.128 * * *$ \\
\hline & 0.0165 \\
\hline \multirow[t]{2}{*}{ PANPR } & $-0.0895 * * *$ \\
\hline & 0.0178 \\
\hline \multirow[t]{2}{*}{ PANFS } & -0.00253 \\
\hline & 0.00511 \\
\hline \multirow[t]{2}{*}{$S D$} & $-0.0000858 * * *$ \\
\hline & 0.0000124 \\
\hline \multirow[t]{2}{*}{ CONS } & $-3.018 * * *$ \\
\hline & 0.296 \\
\hline R-Sqr Within & 0.637 \\
\hline R-Sqr_Between & 0.403 \\
\hline R-Sqr Overall & 0.42 \\
\hline
\end{tabular}

